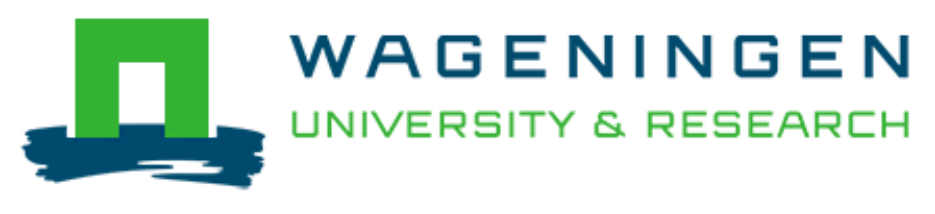

\author{
Fertile cities: Nutrient management practices in urban agriculture \\ Wielemaker, R., Oenema, O., Zeeman, G., \& Weijma, J.
}

This is a "Post-Print" accepted manuscript, which has been published in "Science of the Total Environment"

This version is distributed under a non-commercial no derivatives Creative Commons (c) (1) $\otimes(\theta$

(CC-BY-NC-ND) user license, which permits use, distribution, and reproduction in any medium, provided the original work is properly cited and not used for commercial purposes. Further, the restriction applies that if you remix, transform, or build upon the material, you may not distribute the modified material.

Please cite this publication as follows:

Wielemaker, R., Oenema, O., Zeeman, G., \& Weijma, J. (2019). Fertile cities: Nutrient management practices in urban agriculture. Science of the Total

Environment, 668, 1277-1288. https://doi.org/10.1016/j.scitotenv.2019.02.424 


\title{
FERTILE CITIES: NUTRIENT MANAGEMENT PRACTICES IN URBAN AGRICULTURE
}

\author{
Rosanne Wielemakera, Oene Oenema ${ }^{b, c}$, Grietje Zeeman ${ }^{a, d}$, Jan Weijma ${ }^{a, d,{ }^{*}}$ \\ a Sub-department of Environmental Technology, Wageningen University, Wageningen, The Netherlands \\ ${ }^{b}$ Department of Soil Quality, Wageningen University, P.O. Box 47, 6700 AA Wageningen, The Netherlands \\ Wageningen Environmental Research, P.O. Box 47, 6700 AA Wageningen, The Netherlands \\ ${ }^{\mathrm{d}}$ LeAF, 6708 WG Wageningen, The Netherlands
}

*Corresponding author, P.O. box 17, 6700 AA Wageningen, jan.weijma@wur.nl

\begin{abstract}
Cities are increasingly targeted as centers for sustainable development and innovation of food systems. Urban agriculture (UA) is advocated by some as a multi-faceted approach to help achieve urban sustainability goals, as it provides possible social, economic and environmental benefits. The role of UA in restoring resource cycles receives increasing attention, especially with regard to assimilating urban waste. However, there is little information on how nutrients are managed in UA in industrialized countries. To examine nutrient management in UA, data was collected from a total of 25 ground-based UA initiatives in the Netherlands on i) preferences for types of fertilizers, and ii) quantity and quality of fertilizers used including nutrient composition and organic matter content. The main inputs at urban farms were compost and manure, high in organic matter content. The total nutrient inputs were compared to nutrient demand based on crop nutrient uptake in order to determine nutrient balances. Results show that mean nutrient inputs exceeded mean crop demand by roughly $450 \%$ for total nitrogen, $600 \%$ for phosphorus and $250 \%$ for potassium. Mean inputs for plant-available nitrogen were comparable to crop uptake values. The surpluses, particularly for phosphorus, are higher than fertilizer application limits used for conventional farming in The Netherlands. While nutrient input calculations were subject to several uncertainties, e.g., due to lack of accuracy of the data supplied by the farmers, results show a salient indication of over-fertilization and thus a suboptimal nutrient use. If UA continues to expand across cities these observed nutrient surpluses may pose a risk for local surface waters and groundwater as well as soil quality. The need to improve nutrient management in UA is evident. Soil tests, harvest logging and book keeping of nutrient inputs would improve data quality and may help balance nutrient inputs with nutrient outputs.
\end{abstract}

Keywords: urban farming, nitrogen, phosphorus, potassium, organic matter, fertilizer use 


\section{Introduction}

The long-term sustainability of urban areas has increasingly been called into question due to their dependency on non-renewable resources (McDonnell and MacGregor-Fors, 2016, Rees and Wackernagel, 1996). In response, the concern about the role and contribution of cities to sustainable development has prompted research agendas that regard cities as places that concentrate opportunities for change (Revi and Rosenzweig, 2013, Voytenko et al., 2016, Wolfram and Frantzeskaki, 2016). The production of food in or around urban areas, generally known as urban agriculture (UA), has been proposed by many as an effective intervention to address various issues of urban sustainability (Ackerman et al., 2014, Deelstra and Girardet, 2000, Pearson et al., 2010, Smit et al., 1996, Specht et al., 2013). Especially the diversity in activities, scales, and purposes of UA offers ample opportunities to integrate UA in the built environment and to contribute to various sustainability goals. UA has been advocated to increase local food provisioning, reduce supply chains and transportation distances, increase urban green, reduce the urban heat island effect, increase urban water retention and infiltration, increase bio-diversity in cities, provide opportunities for employment, education and recreation, and foster community cohesion (Lorenz, 2015, Mok et al., 2014, Artmann and Sartison, 2018). UA has also been identified as an auspicious component in repairing biological resource cycles within the built environment (Deelstra and Girardet, 2000, Drechsel and Kunze, 2001, Smit and Nasr, 1992). As such, water, energy, and materials can be recycled between UA and other urban functions.

Cities currently import nutrients contained in food and materials and discharge these as solid waste and wastewater streams with only meager nutrient and organic matter (OM) recovery and reuse. By assimilating these nutrients as composts and bio-fertilizers, UA could reintroduce nutrients into the food system and contribute to restoring the nutrient cycle. The use of compost and animal manure is a widespread practice on urban farms (Metson and Bennett, 2015). These soil amendments, high in OM, positively enhance soil quality. Increased soil OM and soil porosity facilitate water infiltration and water retention, serving as buffers during heavy rainfall (Taylor and Lovell, 2014) and retain water longer during episodes of drought. Soils with a history of urban uses such as housing, industrial production, and disposal activities, are often nutrient-poor, compacted and low in organic carbon. These urban soils may benefit from added soil amendments and farming practices (Lorenz, 2015). Moreover, using urban compost as well as other urban organic waste streams, allows urban farms to facilitate nutrient cycling on a local scale (Dewaelheyns et al., 2013). Metson and Bennett (2015) have shown that $73 \%$ of inputs used in urban farms in Montreal, Canada originated from local sources including green waste compost, vermicompost, and locally-produced manure. Grard et al. (2015) demonstrated the value of using urban organic waste as a growing substrate on rooftop farms in France; results indicated high crop yields and low levels of heavy metals in the harvested crops compared to European norms ( $N$ 1881/2006). The use of nutrients recovered from human excreta in UA can also contribute to closing urban nutrient cycles as shown by Chrispim et al. (2017) and Wielemaker et al. (2018). Increased technology developments in this field provide opportunities for nutrient recovery and reuse in UA in the form of fertilizers or soil amendments.

Despite the potential benefits for improved urban soil quality and increased nutrient availability, intensive UA production systems and fertilization practices can also result in negative ecological effects, both locally and regionally (Lorenz, 2015, Safi, 2011, Taylor and Lovell, 2014). The eager use of fertilizers and the lack of careful management of nutrients by urban farmers can lead to surpluses of macronutrients, nitrogen (N), phosphorus (P) and potassium (K), (Huang et al., 2006, Metson and Bennett, 2015, Wielemaker et al., 2018, Witzling et al., 2011), as well as the accumulation of trace metals, such as cadmium and copper (Lorenz, 2015) (Hargreaves et al., 2008).

Urban farms often follow organic farming practices (with or without certification), which means that they are limited to using the types of fertilizers that are permissible in organic agriculture. Commonly organic amendments such as manure and composts are the main fertilizer source (Bergström et al., 2009). When these amendments are applied at a rate to meet the $\mathrm{N}$ requirement of crops, the amounts of P and K applied often exceed crop requirements (Eghball, 2002, Maltais-Landry et al., 2015, Maltais-Landry et al., 2016, Mikkelsen and Hartz, 2008). Witzling et al. (2011) found high nutrient levels in community gardens in Chicago, with $\mathrm{P}$ and $\mathrm{K}$, and sometimes $\mathrm{N}$ levels exceeding soil fertility recommendations required for optimal crop growth. Similarly, Metson and Bennett (2015) found a surplus of $0.316 \mathrm{Gg} \mathrm{P} \mathrm{yr}^{-1}$ in surveyed urban farms in Montreal in 2012 (averaging to $1013 \mathrm{~kg} \mathrm{P}^{-1} \mathrm{yr}^{-}$ $\left.{ }^{1}\right)$. Another study on home gardens in Flanders, Belgium found $89 \%$ of vegetable gardens to fall under soil fertility class 'high' for soil P content (Dewaelheyns et al., 2013). The over-fertilization of P may result in the saturation of the soil P sorption capacity and increased $\mathrm{P}$ leaching and run-off, leading to environmental drawbacks such as eutrophication of surface waters (Schröder and Neeteson, 2008, Van Grinsven et al., 2016, Maltais-Landry et al., 2016). The build-up of any nutrient in soils to beyond recommended levels is an inefficient use of resources; it decreases nutrient use efficiency and can result in soil-nutrient imbalances and/or unfavorable pH levels (Mikkelsen and Hartz, 2008, Tian and Niu, 2015).

In recent decades UA has been gaining ground in various forms such as allotment gardens, community gardens, harvest farms and commercial farms, across open spaces, rooftops, greenhouses, and as indoor farms (Lorenz, 2015, Thomaier et al., 2015). This trend is also visible in the Netherlands. There is, however, little information on how nutrients are managed on urban farms, which kinds and amounts of fertilizer inputs are used, their origin, and how current practices relate to the current regulatory frameworks for nutrient management in agriculture (i.e., Manure and Fertilizers Act). Research on nutrient budgeting has extensively been conducted in developing countries, such as Vietnam, China, Afghanistan, and several African countries (e.g., Abdulkadir et al., 2013, Huang et al., 2006, Khai et al., 2007, Safi, 2011, Wang et al., 2008). Previous studies on UA in industrialized countries primarily highlight the economic and social facets of UA (e.g., Duchemin et al., 2008, Smit et al., 1996, Specht et al., 2015, Thomaier et al., 2015, Zasada, 2011), and only few studies focus on nutrient management (e.g., Dewaelheyns et al., 2013, Grard et al., 2015, Metson and Bennett, 2015, Wielemaker et al., 2018). If UA is to play a role in the closing of urban nutrient cycles, as is advocated by many (Goldstein et al., 2016, LeGrand et al., 2014, Grard et al., 2015), it is important to first quantify the current fertilizer use in UA and evaluate the contribution of UA to nutrient recycling.

The overall objective of this study was to evaluate nutrient use in UA farms in the Netherlands, a densely populated and industrialized country increasingly implementing UA. While stimulating UA has benefits across social, economic, and environmental facets, careful consideration of the accumulative effects of farm practices needs to be understood. We conducted interviews with ground-based UA farms (sizes between 0.1-1.7 ha) across cities to collect information on farmer preference for the type of nutrient inputs (fertilizers, manures, composts, soil amendments). We quantified N, P, and K (NPK) inputs, the three primary macronutrients, at farm level. In addition, OM inputs were also quantified, as soil OM is broadly recognized as an important 
aspect of soil quality and fertility (Hijbeek et al., 2017). The calculations allowed us to evaluate fertilization practices and identify over or under fertilization for NPK compared to crop nutrient uptake as well as compared to legal application limits for N and P.

\section{Methods \\ 2.1. Selection of UA Initiatives, Interviews and Data Collection}

The definition of UA used in this research is: the production of food in and around cities for the purpose of feeding local populations. Starting with an initial inventory (compiled via an internet search, word of mouth, and snowball sampling) of UA initiatives ( $n=60$ ) located across various cities, a final selection of 25 urban farms was included in this study, using the following criteria: (i) willingness to participate, and (ii) ability to provide quantitative data. Only ground-based urban farms were included in this study, which are the dominant type of urban farming in the Netherlands.

Interviews were conducted in person and onsite, or via telephone, with the head farmer or a farm volunteer between May 2017 March 2018 using a semi-structured questionnaire (see Supplemental Information). Onsite surveying was preferred as it allowed for additional data collection through observation (e.g. cultivated area, management, maintenance of composting facilities, crop types) (Cohen and Crabtree, 2006). The semi-structured interviews were advantageous for both interviewer and interviewee as they intended to be conversational and allowed for flexibility to enquire for details when needed. Most interviews conducted in person were voice-recorded (with consent from the interviewees) and later transcribed to distill data for data processing; interviews conducted via telephone were not voice-recorded. To clarify or verify collected information, the interviews were followed-up with questions via email or telephone.

Data collected during the interviews, both qualitative data on farmer practices and preferences, and quantitative data on nutrient inputs, were processed per farm separately, as well as compounded into data spreadsheets to facilitate comparison. Nutrient contents of manure, compost, and organic fertilizers were derived from the labels of bags or from literature (see Supplemental Information). Occasionally farmers were able to present results of chemical analyses of the manures or composts applied on their farms; when available, we used these values. An overview of the data collected, data sources and assumptions (when inputspecific information was not available), and of the specifications used to make nutrient input calculations is provided in the Supplemental Information.

\subsection{Data Processing and Analysis}

Total inputs for OM and NPK were calculated, and for comparison across farms, inputs were expressed as $\mathrm{kg} \mathrm{ha}^{-1} \mathrm{yr}^{-1}$. Inputs of NPK were compared with the uptake of NPK by crops commonly grown by UA initiatives. Reference values were used, and not an account of what was actually grown on each farm, because farmers could not supply detailed information on crops planted and respective harvests. Inputs were also compared to the legal application limits (2017) for $\mathrm{N}$ and $\mathrm{P}$ according to the Manure and Fertilizers Act (Meststoffenwet, 1986)

To assess the adequacy of soil OM inputs, these were expressed in terms of effective organic matter (EOM). EOM in manure, composts, and other organic fertilizers is defined as the fraction of OM that remains in the soil one year after its application to the soil (de Haan and van Geel, 2013). The amount of EOM inputs $\left(\mathrm{kg} \mathrm{yr}^{-1}\right)$ at each farm was calculated using Equation 1, where HC stands for the humification coefficient (\%), as reported by de Haan and van Geel (2013).

$\mathrm{EOM}=\mathrm{HC} * \mathrm{OM}$

Equation 1

Since plants acquire $\mathrm{N}$ from the soil only in plant-available forms, total $\mathrm{N}$ inputs $\left(\mathrm{kg} \mathrm{yr}^{-1}\right)$ per farm were also expressed in terms of plant-available nitrogen (PAN) inputs $\left(\mathrm{kg} \mathrm{yr}^{-1}\right)$. PAN indicates the fraction of the total $\mathrm{N}\left(\mathrm{N}_{\mathrm{tot}}\right)$ input $\left(\mathrm{kg} \mathrm{yr}^{-1}\right)$ that is available to the plants during the first year after application. It also accounts for the $\mathrm{N}$ that is vulnerable to losses via leaching, denitrification, and (when in ammonium form) volatilization. The amounts of PAN were estimated for each fertilizer, using Equation 2 and fertilizer $\mathrm{N}$ equivalency $\left(\mathrm{CN}_{\text {tot }}\right)$, expressed as percentage coefficients (\%). Fertilizer $\mathrm{N}$ equivalencies for composts, manures, and wastes are usually below $100 \%$, because the organically bound $\mathrm{N}$ has to be mineralized first to ammonium- $\mathrm{N}$ forms (van Dijk et al., 2005). We assumed that all $P$ from composts, manures, and wastes becomes available at similar rates as synthetic $P$ fertilizers on the longer term, and hence the fertilizer $\mathrm{P}$ equivalency for the $\mathrm{P}$ inputs was set at $100 \%$. Further, we assumed that all $\mathrm{K}$ is available and hence the fertilizer K equivalency was also set at $100 \%$ for all fertilizers and soil amendments (de Haan and van Geel, 2013).

Plant available $\mathrm{N}(\mathrm{PAN})=\mathrm{CN}_{\text {tot }}{ }^{*} \mathrm{~N}_{\text {tot }}$

Equation 2

The total nutrient inputs were then compared to nutrient demand based on crop nutrient uptake to determine nutrient balances NPK uptake by crops, and thus withdrawal in harvested biomass, $\left(\mathrm{kg} \mathrm{ha}^{-1} \mathrm{yr}^{-1}\right)$ were retrieved from two literature sources: Bosch and De Jonge (1989) and Fink et al. (1999).

The Manure and Fertilizers Act of The Netherlands regulates $\mathrm{N}$ and $\mathrm{P}$ inputs to agricultural land via manure, and $\mathrm{N}$ and $\mathrm{P}$ application limits ('gebruiksnormen') (van Grinsven and Bleeker, 2016). Manure application limits are expressed in total N and are $170 \mathrm{~kg} \mathrm{ha}^{-1} \mathrm{yr}^{-1}$ for arable land, and 170 to $250 \mathrm{~kg} \mathrm{ha}^{-1} \mathrm{yr}^{-1}$ for grassland, depending on a farm-specific permit (derogation). Application limits for $\mathrm{N}$ (expressed in PAN) indicate the annual allowance of $\mathrm{N}$ per hectare per crop and soil type, and may vary with crop yield (RVO, 2017b). Legal fertilizer N equivalencies (“werkingscoëfficiënt") apply when calculating $\mathrm{N}$ application limits (RVO, 2014). Application limits for $P$ indicate the annual allowance of $P$ per hectare and varies relative to soil $P$ content. In this study, the $\mathrm{N}$ and $\mathrm{P}$ application limits for 2017 were used for comparison. While commonly no fertilizer $\mathrm{P}$ equivalency (CP (\%)) is used for $\mathrm{P}$ inputs $\left(\mathrm{kg} \mathrm{yr}^{-1}\right)$, the Manure and Fertilizers Act acknowledges that approximately half of the $\mathrm{P}$ in composts is soil-bound $\mathrm{P}$ and therefore uses a fertilizer P equivalency (CP) of $50 \%$ for composts (RVO), calculated using Equation 3 . All other fertilizers and soil amendments were counted with a $100 \%$ equivalent. There are no application limits for $\mathrm{K}$ in the Manure and Fertilizers Act.

Available $\mathrm{P}($ compost $)=\mathrm{CP} * \mathrm{P}$

Equation 3 


\section{Results and Discussion}

4.1. Characterization of the selected urban farms

A total of 25 UA initiatives (Table 1) were interviewed in several cities across the Netherlands (Figure 1): Amsterdam (5), Apeldoorn (1), Culemborg (1), Dordrecht (3), Groningen (1), Haren (1), Leiden (1), Maastricht (1), Middelburg (1), Rotterdam (5), 'sHertogenbosch (1), Utrecht (1), Veenhuizen (1), and Wageningen (3). The majority of the farms were established after 2005 with over half established after 2012 . Only a handful of farms $(n=5)$ were over 1 ha in size, with $73 \%$ smaller than 0.5 ha. All farms showed ties to the local community and farmers emphasized the social benefits of their initiatives, including education, awareness raising, community building, and support for low-income and vulnerable groups. Meanwhile, over half of the farms had a commercial objective. The produce from these farms supplied own or local restaurants, were sold through membership shares (CSA), or were sold on-site or at local markets.

With the exception of two farms, the initiatives can be classified as ground-based-non-conditioned (GB-NC). Goldstein et al. (2016) defines this typology as: occurring directly on the ground (as opposed to in or on a building) and connected to the ambient environment (in contrast to e.g., greenhouses). The other two farms can be classified as ground-based-conditioned, growing in raised beds within a frame (contained soil). A few of the farms also managed one or more smaller hoop-house(s) or greenhouse(s) for season extension. For a more detailed account of the farms, and an overview of the interview data can be found in the Supplemental Information.

In total $77 \%$ of the interviewees were satisfied with the crop yields. Almost a quarter were less content, which they related to poor yields, lack of labor force, lack of mechanization, or poor soil quality. All farmers listed measures to further improve harvests, including crop rotation and planning, pest, disease and weed management, and nutrient and soil $\mathrm{pH}$ management. The majority of the farmers considered their farming practices to be sustainable for a host of reasons. Many alluded to their organic or ecological farming practices referring to the use of organic manure, biological-control of pests, the absence of pesticide use and the use of a crop rotation plan. Onsite composting, waste management and recycling, rainwater harvest and reuse, green energy use and reducing transport and packaging of products were reasons given to support their sustainability claims. Many farmers also considered their role in raising awareness amongst the community as one of their main contributions to sustainability.

All farmers also considered their resource management to be sustainable. The use of local, renewable, and/or organic sources of fertilizers as opposed to chemical fertilizers was the main reason provided. $35 \%$ of the farmers mentioned their onsite composting efforts as indication of their sustainable resource management. A meagre three of the farms considered their resource management to be less optimal because of the use of external inputs and uncertainty regarding the soil nutrient balance. To improve nutrient management many farmers indicated that a soil analysis would be appropriate, as well as (improved) onsite composting.

The preferences for fertilizers varied between farms. None of the farmers preferred synthetic fertilizers but rather preferred certified organic fertilizers derived from plant and animal residues, and sourced as locally as possible. However, in practice, farmers did not always/only use certified organic fertilizers, nor fertilizers sourced locally. Manure inputs at some farms were sourced onsite (i.e. from own farm animals), some were sourced directly from nearby (petting) farms, some from farms outside of the city, and others purchased packaged manure from retailers. Some farmers were adamantly against the use of fertilizers made from animal waste such as bone and blood meal, and sources of manure that could contain traces of antibiotics (administered to the animals). Most farmers conveyed that their fertilizer use practices were based on a mix of experience $(62 \%)$, feeling $(42 \%)$, knowledge $(54 \%)$, and trial-and-error $(50 \%)$; a minority indicated that advice found in literature $(23 \%)$, on the packaging (15), or from experts $(27 \%)$ and legislation $(23 \%)$ guided their fertilizer use.

\subsection{Fertilizer, organic matter and nutrient inputs}

Table 1 shows which types of fertilizer inputs were used. While some inputs were produced onsite (e.g. farm-made composts and manure from own farm animals), all farms used at least one fertilizer input from external sources (produced off-site). Compost (used at $80 \%$ of the farms), manure $(60 \%)$, and/or some other organic soil amendment $(24 \%)$ were the main inputs. Supplemental macronutrient $(40 \%)$, micronutrient $(20 \%)$ and potassium fertilizers $(16 \%)$ were also used at some farms. Calcium-rich soil amendments were also used (24\%), primarily to modify soil $\mathrm{pH}$. The variation in types and amounts of fertilizers used by farmers is reflected by the variation in the total nutrient and organic matter inputs calculated for each farm (Table 1).

\subsubsection{Organic Matter}

The calculations for farm inputs show a partiality for fertilizers rich in OM; particularly compost and manure contributed to OM loads with total OM inputs ranging between 700 and $138,100 \mathrm{~kg} \mathrm{OM} \mathrm{ha}^{-1} \mathrm{yr}^{-1}$ (Table 1 and Figure 2). Whether the application of organic inputs increases soil OM depends on the current amount of organic matter in the soil, the type of organic input applied, crop type, and crop residue management, as well as temperature, humidity, soil texture, and soil cultivation (Hijbeek et al., 2017). As found by Loveland and Webb (2003), it is difficult to establish a critical level for soil organic matter for temperate regions. A steady soil OM input-output balance requires a total annual supply of EOM that is equal to the amount of soil OM that is degraded annually. Degradation of soil organic matter depends on soil characteristics such as soil type, soil pH, soil moisture, and temperature and $\mathrm{C} / \mathrm{N}$ ratio, as well as on the level of soil cultivation. The rate of degradation of soil organic matter may vary between $1-5 \%$ per year. For agricultural land in The Netherlands, it has been estimated at the average degradation is $2000 \mathrm{~kg}$ $\mathrm{OM} \mathrm{ha}^{-1} \mathrm{yr}^{-1}$ (de Haan and van Geel, 2013). Therefore, to replenish soil OM degradation, an average input of $2000 \mathrm{~kg} \mathrm{EOM} \mathrm{ha-}^{-1}$ $\mathrm{yr}^{-1}$ is recommended \{de Haan, $2013 \# 38$ \}. We observed that the average EOM input was much larger than the recommended EOM input; $84 \%$ of the farms $(n=22)$ applied more than $2000 \mathrm{~kg} \mathrm{EOM} \mathrm{ha}^{-1} \mathrm{yr}^{-1}$ and $76 \%(n=18)$ of the farms applied more than $5000 \mathrm{~kg} \mathrm{EOM} \mathrm{ha}^{-1} \mathrm{yr}^{-1}$. This indicates that most UA farms increase soil OM content.

\subsubsection{Nitrogen, Phosphorus and Potassium}

NPK inputs differed greatly between farms (Table 1 and Figure 2). Means \pm standard deviations indicate the wide range of inputs across the 25 UA initiatives. For NPK these values were $789 \pm 955 \mathrm{~kg} \mathrm{~N} \mathrm{ha}^{-1} \mathrm{yr}^{-1}, 168 \pm 198 \mathrm{~kg} \mathrm{P} \mathrm{ha}^{-1} \mathrm{yr}^{-1}$, and $625 \pm 698 \mathrm{~kg} \mathrm{~K}^{\circ}$ 
$\mathrm{ha}^{-1} \mathrm{yr}^{-1}$. The variations in inputs for UA farms smaller than $0.3 \mathrm{ha}(\mathrm{n}=15)$ were especially large, and on average higher compared to the inputs for UA farms larger than 0.3 ha $(n=11)$ (Figure 3a). The UA farms with the highest nutrient applications were also amongst the smaller farms. Another relationship was found between the year in which the urban farm was established and the nutrient input. Older farms $(n=9)$, established before 2010, displayed lower nutrient applications (average P application of $45 \mathrm{~kg}$ $\mathrm{ha}^{-1} \mathrm{yr}^{-1}$ ) than younger farms $(\mathrm{n}=16)$ (average $\mathrm{P}$ application $237 \mathrm{~kg} \mathrm{ha}^{-1} \mathrm{yr}^{-1}$ ) (Figure 3b). The highest nutrient applications where on farms with clay soils (Figure 3c). See Supplemental Information for a detailed account of the nutrient loads per UA initiative.

\subsubsection{Comparison of NPK inputs with NPK withdrawal in harvested crops}

Partial NPK input-output balances of UA farms provide an indication of the NPK surpluses or deficits, the potential NPK accumulation in the soil, as well as of the vulnerability of these UA farms for NPK losses to the wider environment. Mean total N inputs $\left(789 \pm 955 \mathrm{~kg} \mathrm{ha}^{-1} \mathrm{yr}^{-1}\right.$ ) were 4 to 5 fold larger than the estimated $\mathrm{N}$ withdrawal via harvested crops (Figure 4a); $\mathrm{N}$ withdrawal averaged to $161 \pm 76 \mathrm{~kg} \mathrm{ha}^{-1} \mathrm{yr}^{-1}$ and $203 \pm 88 \mathrm{~kg} \mathrm{ha}^{-1} \mathrm{yr}^{-1}$, calculated from data extracted from two literature sources respectively (see supplemental information). Independent-sample t-tests (confidence interval percentage 95\%) were conducted to compare the difference in means between $\mathrm{N}$ inputs and the withdrawal values. There was a significant difference in means (two tailed) for total $\mathrm{N}$ inputs and $\mathrm{N}$ withdrawal values found in Bosch and De Jonge (1989) $(p=0.003)$ and Fink et al. (1999) $(p=0.005)$. Mean PAN inputs were only $191 \pm 192 \mathrm{~kg} \mathrm{ha}^{-1} \mathrm{yr}^{-1}$, which fall within the range for the $\mathrm{N}$ withdrawal estimates; the difference in means between PAN inputs and N withdrawal values found in Bosch and De Jonge (1989) $(p=0.480)$ and Fink et al. $(1999)(p=0.779)$ was not significantly different. The large difference between total $\mathrm{N}$ input and PAN input is due to the low fertilizer $\mathrm{N}$ equivalencies $\left(\mathrm{CN}_{\text {tot }}\right)$ for composts, manures, and wastes. These fertilizers release only a small fraction of total $\mathrm{N}$ in plant-available forms in the year of application. However, the residual release of PAN during subsequent years is relatively high, and PAN may accumulate in the soil with continued use of these fertilizers at high rates. UA farmers do seem to account for residual effects, as the total $\mathrm{N}$ input clearly decreased with the age of the farm (Figure $3 b$ ).

Mean $\mathrm{P}$ inputs $\left(168 \pm 198 \mathrm{~kg} \mathrm{ha}^{-1} \mathrm{yr}^{-1}\right)$ were much higher than, and significantly different from, estimated $\mathrm{P}$ withdrawal via harvested crops $\left(24 \pm 12 \mathrm{~kg} \mathrm{ha}^{-1} \mathrm{yr}^{-1}(p=0.001)\right.$ and $32 \pm 13 \mathrm{~kg} \mathrm{ha}^{-1} \mathrm{yr}^{-1}(p=0.002)$, for the two literature sources respectively) (Figure $\left.4 \mathrm{~b}\right)$. $\mathrm{P}$ inputs for $44 \%$ of the farms were below the maximum value of $P$ withdrawal (brussel sprouts $\sim 60 \mathrm{~kg} \mathrm{Pha}^{-1} \mathrm{yr}^{-1}$ ), the remaining $56 \%$ of $\mathrm{P}$ inputs surpassed this maximum value. Mean K inputs $\left(625 \pm 698 \mathrm{~kg} \mathrm{ha}^{-1} \mathrm{yr}^{-1}\right)$ were also much higher than estimated K withdrawal via harvested crops $\left(226 \pm 104 \mathrm{~kg} \mathrm{ha}^{-1} \mathrm{yr}^{-1}(p=0.009)\right.$ and $372 \pm 102 \mathrm{~kg} \mathrm{ha}^{-1} \mathrm{yr}^{-1}(p=0.020)$, for the two literature sources respectively). A total of $36 \%$ of the farms had $\mathrm{K}$ inputs that exceeded even the highest value for $\mathrm{K}$ output via harvested crops (red beet $\sim 460 \mathrm{~kg} \mathrm{ha}^{-1} \mathrm{yr}^{-1}$ ) (Figure $4 \mathrm{c}$ ).

The fertilization adequacy can further be evaluated on the basis of N:P:K mass ratios. Figure 5 shows the position of various common vegetable crops in the triangle based on their NPK contents and normalized to percentages (only selected crops are shown in Figure 5; see Supplemental Information for full list). The mean NPK inputs of the 25 UA farms are also plotted in the triangle. The mean NPK mass ratios of crops at harvest average 40:6:54 (calculated for both Bosch and De Jonge (1989) and Fink et al. (1999)). However, there is a significant variation between crops, for example for radish it is 53:4:43 and for endive 34:4:62). Ratios for the NPK inputs are also shown with PAN (PAN:P:K). The ratios of NPK inputs based on total $N$ (average= 49:10:41) compare more closely to crop uptake ratios than NPK input ratios based on PAN (average $=21: 16: 63$ ), indicating excess input of $\mathrm{P}$ and $\mathrm{K}$ relative to available $\mathrm{N}$. Ratios of NPK inputs across farms are fairly similar with the exception of one farm (UA 15). UA 15 had only input of vermicompost, which has low N:P and N:K ratios.

The 25 urban farms show relatively large mean NPK surpluses and a mismatch between inputs and demands in terms of NPK ratios, both indicating that current nutrient management practices on urban farms are not optimal. The preference among UA farms for manure and compost often leads to high $\mathrm{P}$ and $\mathrm{K}$ loads that exceed plant requirements (Maltais-Landry et al., 2016). While the nutrient surplus exhibited by some of the urban farms do not by default indicate total nutrient losses to the environment directly, they can be used as an integrated measure of nutrient loss potential (Öborn et al., 2003). The surplus may be stored within the system and may be lost to the environment; its dissipation into the environment depends on various factors including rainfall, soil type, and slope, soil tillage, crop type, and application method (Edwards and Withers, 1998, Lord et al., 1999). While some oversupply of $\mathrm{P}$ and $\mathrm{K}$ might be acceptable in single years, since they can be stored in the soil to a larger extent than $\mathrm{N}$, the long term balance would need to indicate ratios similar to those required by crops plus some unavoidable losses (Winker et al., 2009). Two options for improving the nutrient balance include: 1 ) increasing $P$ export by cultivating plants with high plant $P$ concentrations (e.g., grain, potato and cabbage crops) and 2) adjusting fertilizer inputs to better match crop uptake requirements (Maltais-Landry et al., 2016). Reducing over-fertilization of especially P, by simply reducing application rates of composts and manure would result in N under-fertilization, leading to lower crop yields and crop N deficiency (Maltais-Landry et al., 2016, Berry et al., 2002). Shifts in N:P:K ratios are needed. Instead of relying completely on composts and manures, with a constrained N:P stoichiometry, these organic amendments should be replaced by fertilizers with a high $\mathrm{N}: \mathrm{P}$ ratio and/or decoupled nutrients (Maltais-Landry et al., 2016).

\subsubsection{Comparison of $\mathrm{N}$ and $\mathrm{P}$ inputs with legal $\mathrm{N}$ and $\mathrm{P}$ application limits}

Nutrient management practices in the Netherlands have long been discussed and criticized because of the high $\mathrm{N}$ and $\mathrm{P}$ surpluses in Dutch soils (Schröder and Neeteson, 2008, Van Grinsven et al., 2016). The implementation of a series of governmental regulations in the late 1990's (especially in response to the 1991 Nitrate Directive (91/676/EEC)) have halved the mean N surplus from $250 \mathrm{~kg} \mathrm{ha}^{-1}$ in the mid-1990s, and have led to a strong decrease in mean P surpluses since the early 1990s, approaching zero kg ha ${ }^{-1}$ (Van Grinsven et al., 2016). However, while conventional agriculture in the Netherlands has to comply with strict regulations for fertilization according to the Manure and Fertilizers Act, UA falls somewhere between existing categories. Due of their small size ( $<3 \mathrm{ha}$ ), and low number of animals (whose manure amounts to $<350 \mathrm{~kg} \mathrm{~N} \mathrm{yr}^{-1}$ ), these farms have an exemption from the compulsory $\mathrm{N}$ and $\mathrm{P}$ application limits and from nutrient management administration obligations, according to Article 43 of the Implementing Arrangement (Uitvoeringsregeling) of the Manure and Fertilizers Act (Meststoffenwet, 1986).

Further, of the included farms, 10 fall under the land use category for 'agricultural land'; the other farms fall under the following categories: 'recreation' (5), 'built' (4), 'semi-built' (3), and 'industrial' (3) (Kadaster, 2012). If classified as agricultural land, UA would have to adhere to the same regulations as conventional agriculture, with the maximum application rates for agricultural (grass land and arable land) of $35 \mathrm{~kg} \mathrm{Pha}^{-1} \mathrm{yr}^{-1}$ and $170 \mathrm{~kg} \mathrm{~N} \mathrm{ha}^{-1} \mathrm{yr}^{-1}$ (article 2.4.b). However, if classified as "other land" the 
maximum phosphorus application derived from animal manure, compost, recovered phosphorus fertilizers and organic fertilizers made form plant-derived materials (article 2.4.a, Dutch Manure and Fertilizer Act) amounts to $20 \mathrm{~kg} \mathrm{P}_{2} \mathrm{O}_{5}$ ha-1 $\mathrm{yr}^{-1}$. For other land, a one-time dosage of vegetative compost of 200 ton dry matter ha-1 is also permitted (article 2a.1).

Total $\mathrm{N}$ and $\mathrm{P}$ inputs for all 25 farms were compared to the legal application limits (2017) for $\mathrm{N}$ and $\mathrm{P}$ (see Table 2). The $\mathrm{N}$ (as PAN) inputs were on average higher than the mean $\mathrm{N}$ application limits but lower than the highest $\mathrm{N}$ application limit (for white cabbage $=320 \mathrm{~kg} \mathrm{~N} \mathrm{ha}^{-1} \mathrm{yr}^{-1}$ ). Considering that the application standards for $\mathrm{N}$ are given in $\mathrm{ha}^{-1} \mathrm{yr}^{-1}$ per crop, if two or more crops are planted in succession in one year, the application limit is increased to the sum of the individual limits per crop. Total $\mathrm{P}$ inputs are much higher than the $P$ application limits for agricultural land. Total $P$ inputs exceeded the lowest $P$ application limit $(22 \mathrm{~kg} \mathrm{ha}$ $\left.{ }^{1} \mathrm{yr}^{-1}\right)$ on $84 \%$ of the farms and $72 \%$ of the farms exceeded the highest $\mathrm{P}$ application limit $\left(33 \mathrm{ha}^{-1} \mathrm{yr}^{-1}\right)$. The majority of farms that indicated to comply to legal application limits, largely over applied P. Using a fertilizer $\mathrm{P}$ equivalence for compost inputs shifted only one farm from a position of over-application of $P$ to falling within the regulatory limits.

The Manure and Fertilizers Act was implemented to reduce $\mathrm{N}$ and $\mathrm{P}$ pollution of surface waters and groundwater by agricultural practices. However, small urban farms have an exemption from the compulsory $\mathrm{N}$ and $\mathrm{P}$ application limits and from nutrient management administration obligations because these farms have less than 3 ha of agricultural land and/or produce in total less than $350 \mathrm{~kg}$ of manure $\mathrm{N}$ per year on the farm. Because of this exemption, there is also no control and verification. Currently, the number of UA farms is relatively low, and they have a relatively small cultivated area. However, if current nutrient management practices on UA farms persist over long periods, and/or if the number of UA initiatives continues to grow and if new initiatives adopt similar practices, then these practices do raise concern from an environmental perspective. A further increase of the cultivated area will increase the environmental risks. Run-off from urban farms can either enter surface waters, leading to algal blooms, or, for cities with a combined sewer, wastewater treatment plants will have to manage increased nutrient loads from runoff. Equally of concern, the high compost and manure application rates may lead to accumulation of heavy metals in soils, and in vegetables. Heavy metal loads and organic micro pollutants through land application of fertilizers and soil amendments are also regulated by the Manure and Fertilizers Act; approved composts and soil amendments have to comply with heavy metal and micro pollutant concentration limits, and then may be increasingly applied until a maximum application per hectare of $100 \mathrm{~kg} \mathrm{~N}, 35 \mathrm{~kg}$ $\mathrm{P}, 150 \mathrm{~kg} \mathrm{~K}$, or $3000 \mathrm{~kg}$ OM is reached ((RVO, 2017a, RVO, 2017c)). The lack of data on heavy metals and micro pollutant concentrations of the inputs used on UA farms makes it difficult to assess whether concentration limits are exceeded. Regardless, considering that many farms exceed the indicated application limits, most interviewed farms may breach the heavy metal and micro pollutant legislation.

\subsection{Data Uncertainties}

Several uncertainties affected the accuracy to calculate farm-level nutrient inputs, especially given the high-demand for data for this research: 1) the (lack of) accuracy and comprehensiveness of the data supplied by the farmers; 2) the estimates on the nutrient composition of manures and composts; 3 ) the lack of information on past fertilization regimes and soil nutrient stocks; 4) the lack of information of farm management (e.g. tillage practices, fertilizer placement and timing). Despite these limitations, we consider the quality of the partial nutrient balances sufficiently robust to assess the nutrient management practices of UA farms, which was our main goal. For instance, assuming a magnitude of possible error for $\mathrm{N}$ content in manure of $30 \%$ (as used by Mulier et al. (2003) in a similar study), to account for variability in nutrient composition estimates, does not change the main findings of this study (mean PAN inputs only change by $\pm 3 \%$ ). Likewise, the inclusion of past fertilization regimes and the mineralization of organic $\mathrm{N}$ from previous fertilizer applications, would only magnify the surpluses already observed. While $\mathrm{P}$ from previous applications accumulates in the soil, organic nitrogen is further released as PAN; a yearly application of chicken/pig or cow manure, for example, increases the fertilizer N equivalence by 20 and 35\% respectively (de Haan and van Geel, 2013).

The initial intention to conduct full farm-gate balances was discarded early on as collecting data on fertilizers used and the respective amounts applied was challenging enough and farmers could not supply detailed information on crop harvests $\left(\mathrm{kg} \mathrm{yr}^{-1}\right)$ and succession planting. Planting multiple crops in succession throughout a year changes the amount of crop nutrient withdrawal, which could not be accounted for in this study. However a quick analysis considering two crop plantings in a year for comparison returned the following conclusions, which echo the conclusions already presented: 1) The majority of the farms risk under fertilization of PAN, 2) The mean $P$ and $K$ inputs for the UA farms would still exceed $P$ and $K$ crop withdrawal. Especially for $P$, the difference in means between inputs and crop withdrawal, considering two plantings, remains significantly different compared to the two literature sources: Bosch and De Jonge (1989) $(p=0.006)$ and Fink et al. (1999) $(p=0.016)$.

Furthermore, most farmers had not recorded which fertilizers they had used that year and many could provide only rough estimates of the amounts applied, let alone the exact placement and timing of the fertilizer application, and crop residue, mulching, and soil cultivation practices. Detailed farm nutrient balances would however benefit farmers in targeting and improving their nutrient management practices. Periodic soil testing and book keeping of all fertilizer inputs as well as yield and harvest logging, would make it possible to calculate input-output balances at farm resolution. Farm specific data on yield would have allowed for further analyses between fertilizer inputs and respective yield success. To achieve even more complete farm nutrient balances, $\mathrm{N}$ deposition, $\mathrm{N}$ fixation, and nutrient sedimentation could be included.

\section{Conclusions and Outlook}

NPK inputs varied greatly among the 25 UA farms studied. Mean total NPK inputs were much larger than NPK output via harvested crops. There was a considerable range in fertilizer types, with a clear preference for composts and animal manures rich in OM. However, most OM-rich inputs are also the culprit of the excess fertilization due to the small faction of total $\mathrm{N}$ inputs that is plantavailable and their constrained N:P:K stoichiometry. While, mean input of PAN was roughly similar to the mean $\mathrm{N}$ withdrawal via crop uptake, the $\mathrm{P}$ and $\mathrm{K}$ inputs largely exceeded their withdrawal via harvested crops. The persistence of current nutrient management practices on urban farms over long periods, and/or the adoption of similar practices at new urban farms increases the risks of inefficient nutrient management and excessive nutrient losses. While this research is unable to determine whether the excess NPK inputs have accumulated in the soil or are lost to the environment, the excesses do call to attention the need for increasing nutrient use efficiency and merits further examination. Just as conventional agriculture in the Netherlands has to comply with $\mathrm{N}$ and $\mathrm{P}$ application limits, UA initiatives might require similar attention. Longer term monitoring of nutrient inputs, outputs and 
soil nutrient pools will better help determine which targeted measures and tools could assist farmers in improving nutrient use efficiency and better inform whether measures are needed to regulate fertilizer use in UA.

The broader perspective of this study was to examine whether the nutrient demand of UA could be used to assess how much NPK from urban waste streams could be absorbed by UA, so as to achieve effective nutrient recycling within urban boundaries. Currently it is difficult to quantify how much NPK can be assimilated by UA, based on current UA practices, due to the huge diversity in UA practices and limited amounts of quantitative data. Only with a stark decrease in nutrient inputs could actual UA fertilization practices be taken as a point of departure to determine the extent to which UA may assimilate nutrients from urban waste streams to repair nutrient cycles within the built environment. However, in cities saturated with nutrients in solid waste and wastewater, it seems unsuited to perpetuate the current nutrient management practices of UA farms, including importing manure from rural areas to UA. Because UA is inherently urban and thus is in proximity to nutrient sources in waste, UA lends itself for establishing local nutrient cycles, especially for nutrients in forms too costly to export back to other agricultural areas (i.e. voluminous and heavy).

\section{Acknowledgements}

The authors thank MSc. Mathieu Chaix-Bar for conducting interviews with farmers and collecting data. We appreciate the participation of the urban farmers surveyed at each urban agriculture initiative, and thank them for taking the time to answer our questions and share data with us. We also thank Inge de Weerd, former employee at the Nutrient Platform NL, for her explanation of the Dutch Manure and Fertilizers Act as it applies to urban agriculture, and Willem van Geel and Janjo de Haan, from Wageningen Plant Research, for their input on crop yield and crop nutrient uptake. R. C. Wielemaker contributed to this article in relation to the project 'AgriSan: Increasing Urban Self-Sufficiency by Integrating Urban Agriculture and New Sanitation', funded by The Netherlands Organisation for Scientific Research (NWO) under grant agreement 869.15.016. 
Table 1 Participating urban agriculture initiatives with general farm characteristics, fertilizer use, and nutrient and organic matter inputs

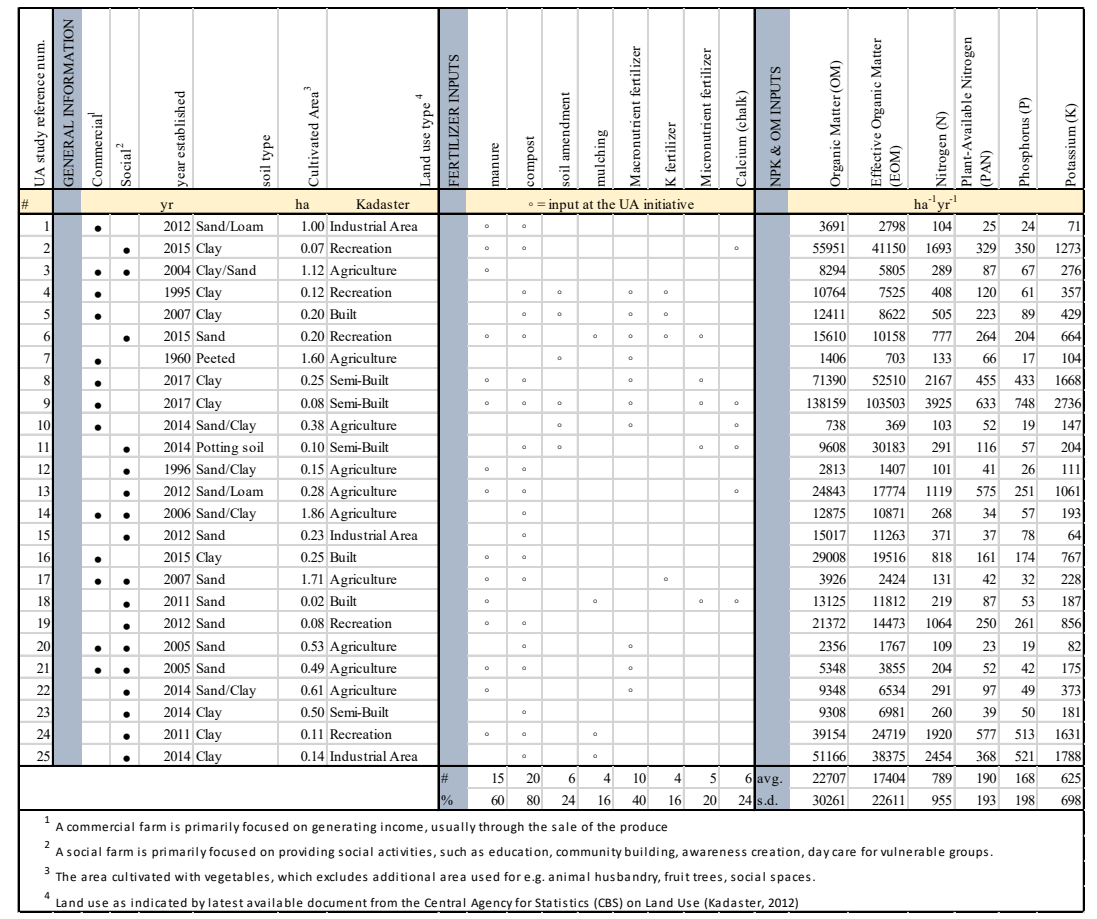

Table 2. Comparison of mean nutrient inputs at urban farms (this study) to legal nitrogen $(\mathrm{N})$ and phosphorus $(\mathrm{P})$ application limits for conventional farming according to the Dutch Manure \& Fertilizers Act

\begin{tabular}{|c|c|c|c|c|c|c|c|c|c|c|c|c|}
\hline & \multicolumn{7}{|c|}{ Nitrogen } & \multicolumn{5}{|c|}{ Phosphorus } \\
\hline & \multicolumn{2}{|c|}{$\begin{array}{c}\text { N Input at UA } \\
\text { farms }\end{array}$} & \multicolumn{5}{|c|}{ N Application Limits (Soil Type) } & \multicolumn{2}{|c|}{$\begin{array}{l}\text { P Input at UA } \\
\text { farms }^{1}\end{array}$} & \multicolumn{3}{|c|}{$\begin{array}{l}\text { P Application Limits } \\
\text { (Soil P content) }\end{array}$} \\
\hline & $\begin{array}{c}\text { Total } \\
\mathrm{N}\end{array}$ & PAN & Clay & $\begin{array}{l}\text { Sand- } \\
\text { NWC }\end{array}$ & Sand-S & Loam & Peat & $\mathrm{P}_{2} \mathrm{O}_{5}$ & $P$ & Low & Medium & High \\
\hline & \multicolumn{2}{|c|}{$\mathrm{kg} \mathrm{ha}^{-1} \mathrm{yr}^{-1}$} & \multicolumn{5}{|c|}{$\mathrm{kg} \mathrm{N} \mathrm{ha}^{-1} \mathrm{yr}^{-1} \mathrm{crop}^{-1}$} & \multicolumn{2}{|c|}{$\mathrm{kg} \mathrm{ha}^{-1} \mathrm{yr}^{-1}$} & \multicolumn{3}{|c|}{$\mathrm{kg} \mathrm{P}_{2} \mathrm{O}_{5} \mathrm{ha}^{-1} \mathrm{yr}^{-1}$} \\
\hline Mean & 789 & 197 & 209 & 187 & 152 & 152 & 194 & 267 & 116 & 75 & 60 & 50 \\
\hline s.d. & 955 & 189 & 66 & 59 & 45 & 45 & 63 & 272 & 119 & - & - & - \\
\hline
\end{tabular}

The Manure and Fertilizers Act uses a fertilizer $\mathrm{P}$ equivalency (CP) of $50 \%$ for composts. For comparison to $\mathrm{P}$ application limits, this equivalency was used when applicable to composts to calculate UA farm inputs. 


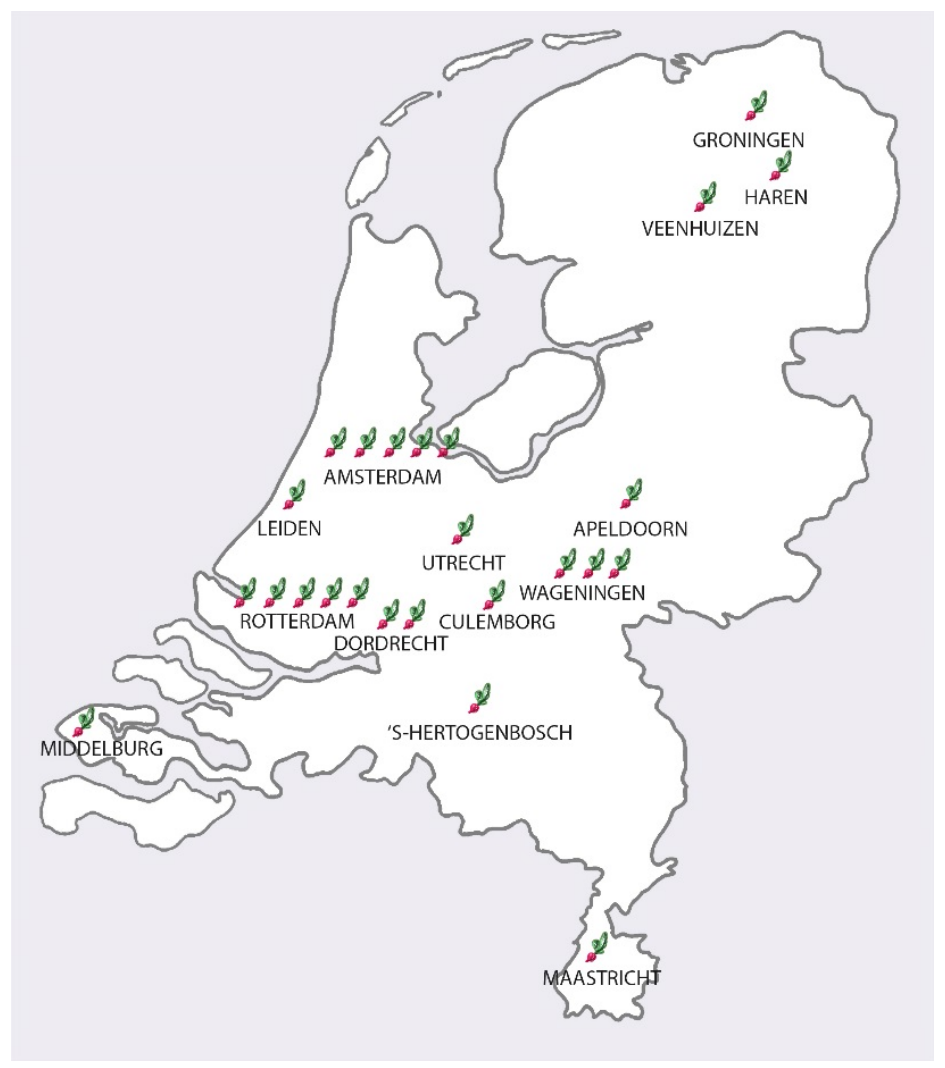

Figure 1. Map of the 25 interviewed urban agriculture initiatives across cities in the Netherlands

NUTRIENT \& ORGANIC MATTER INPUTS
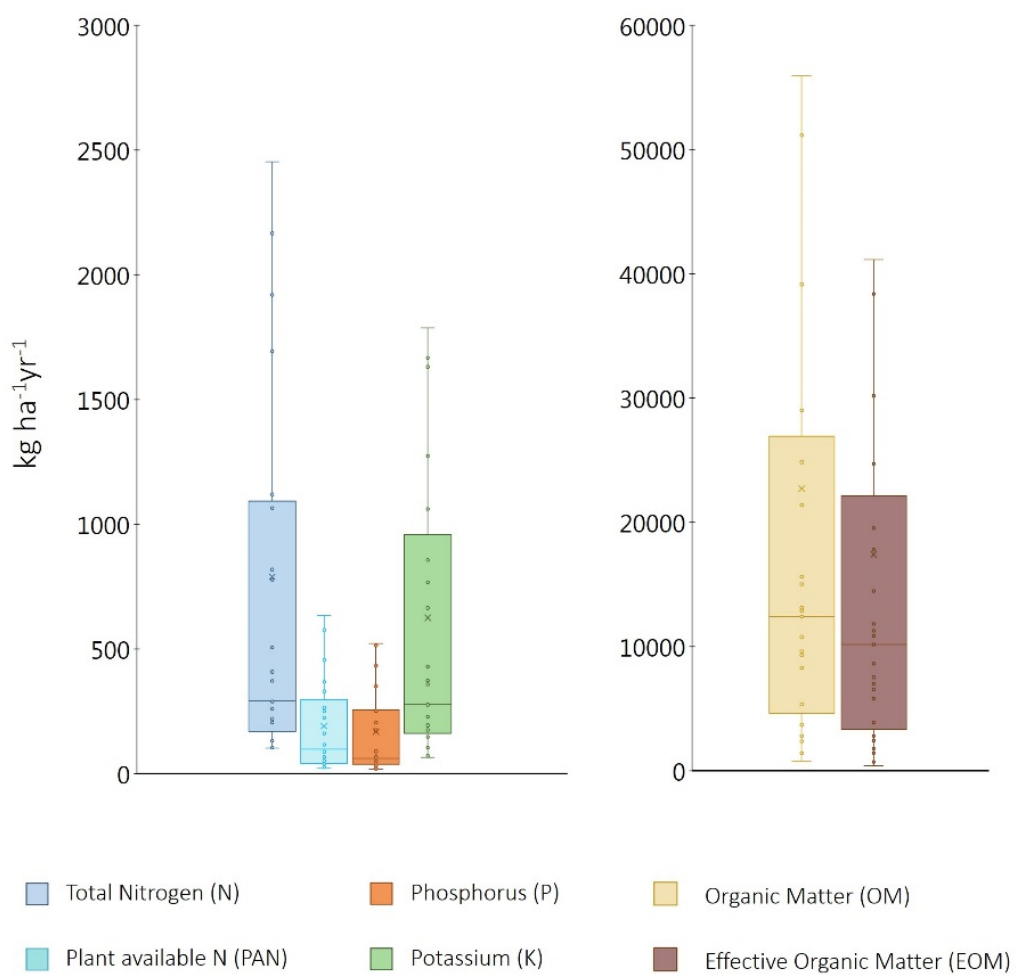

Figure 2. Box plots of organic matter (OM) and effective organic matter (EOM) inputs (a) and nitrogen (N), plant-available nitrogen (PAN), phosphorus $(P)$ and potassium $(K)$ inputs $(b)$ for all UA initiatives. Boxes show the interquartile range ( 25 to $75 \%$ values). The line in the boxes shows the median value and the ' $x$ ' shows the mean value. Whiskers indicate the total range of the values, outliers (>1.5 interquartile range) excluded. 

Total Nitrogen (N)
Phosphorus (P)
Organic Matter (OM)
Plant available N (PAN)
Potassium (K)
- Effective Organic Matter (EOM)

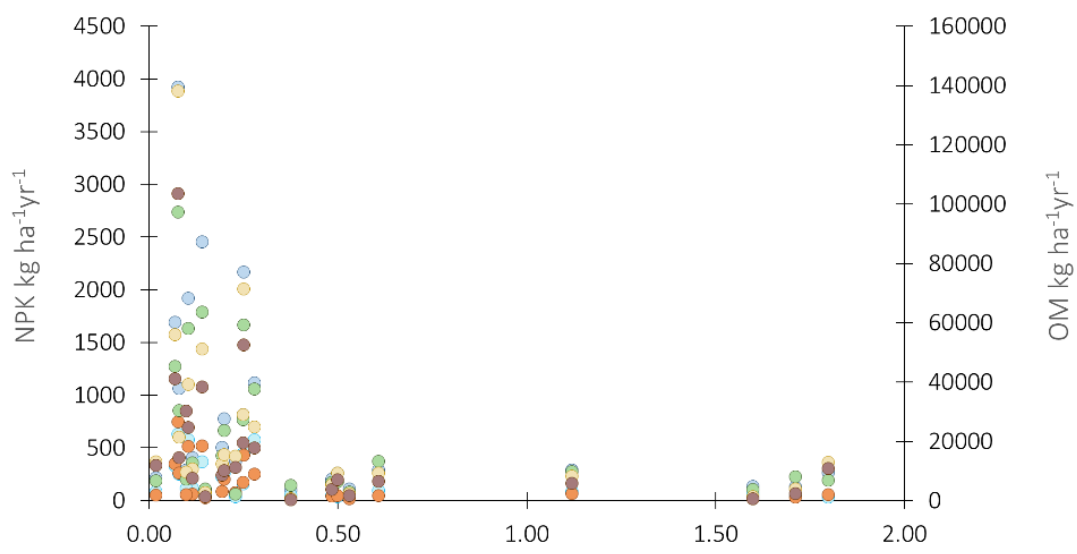

a.

Hectares

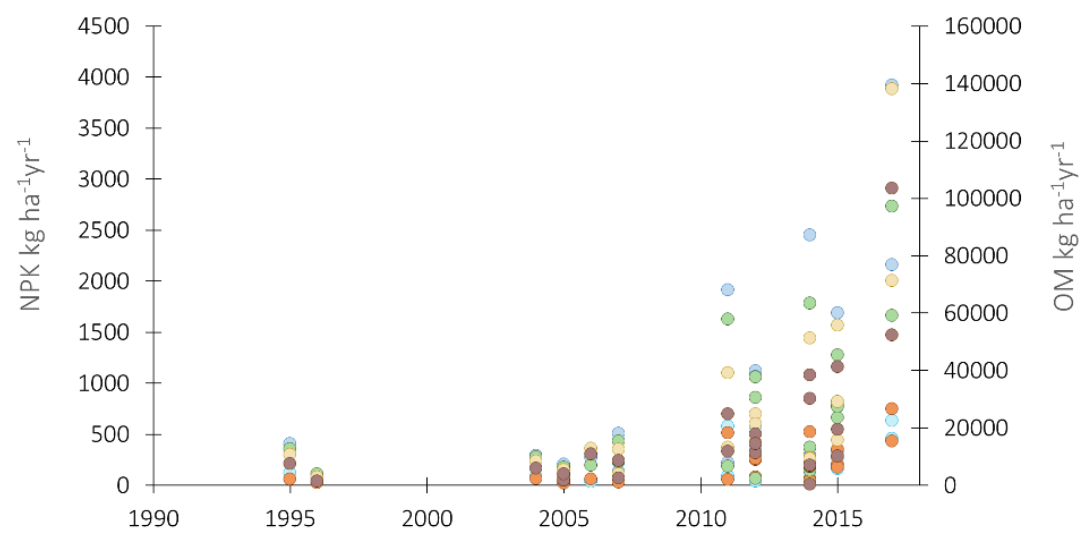

b.

Year Established

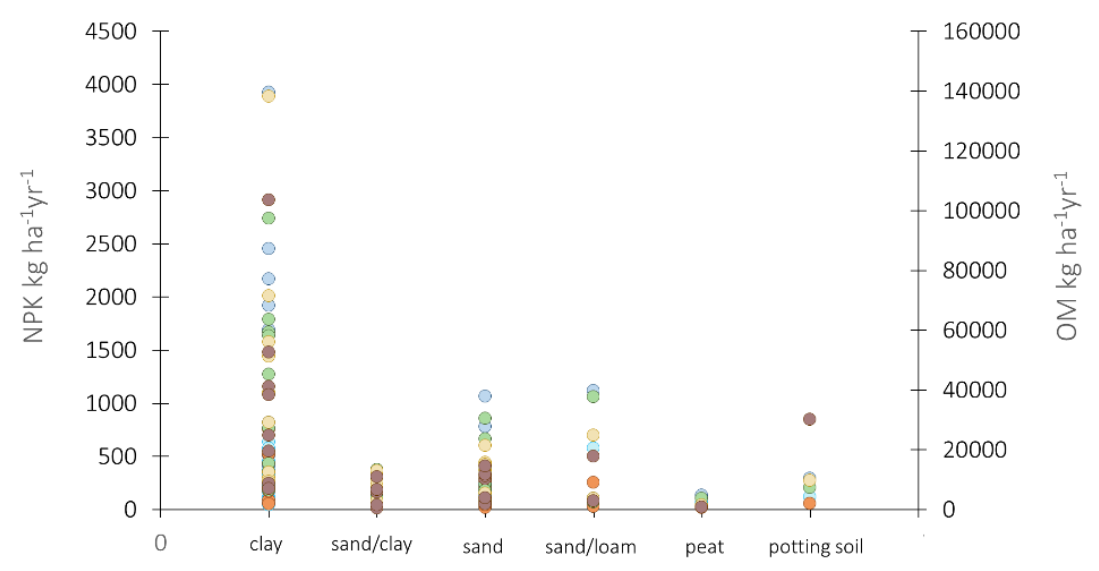

c.

Soil Type

Figure 3. (a) Nitrogen $(\mathrm{N})$, phosphorus $(\mathrm{P})$ and potassium $(\mathrm{K})$ and organic matter $(\mathrm{OM})$ inputs plotted (a) against farms size, (b) year of farm establishment, and (c) per soil type 


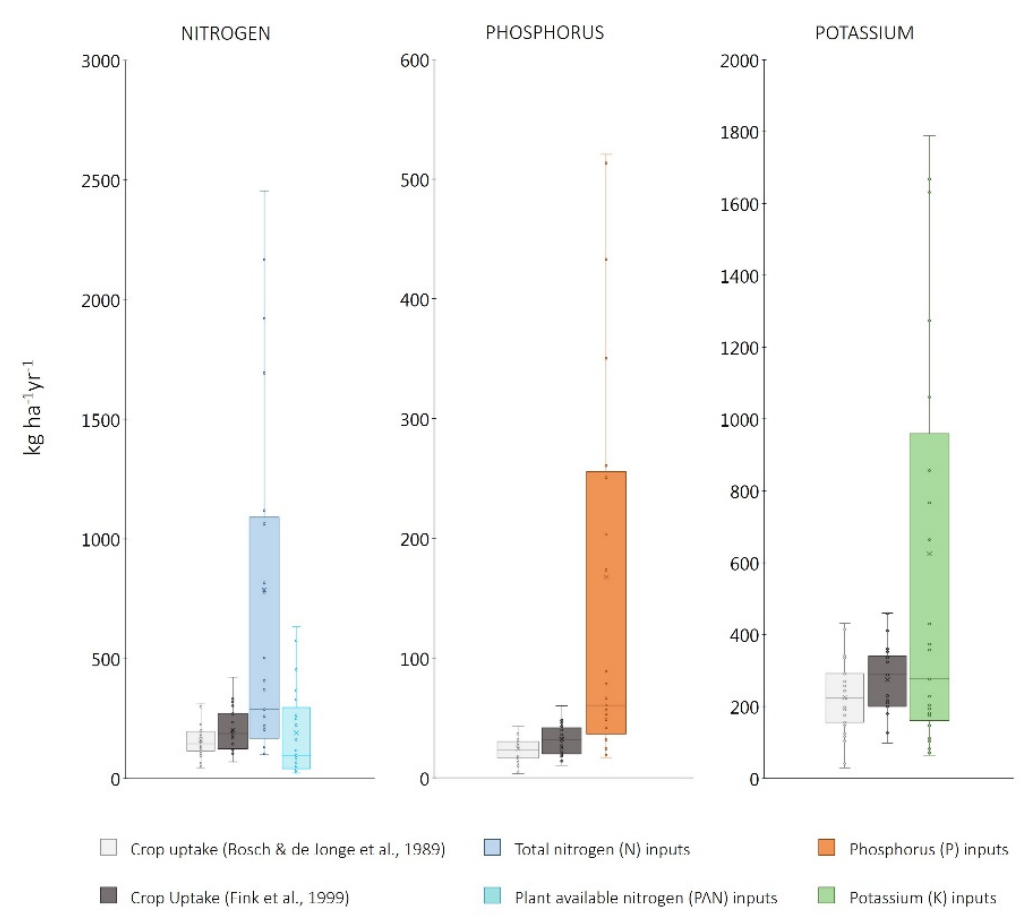

Figure 4. Nitrogen $(\mathrm{N})$, phosphorus $(\mathrm{P})$ and potassium $(\mathrm{K})$ inputs of the 25 interviewed farms compared to NPK crop uptake retrieved from two studies (Bosch and De Jonge, 1989, Fink et al., 1999). Total $\mathrm{N}$ and plant-available N (PAN) inputs compared to crop uptake of N (a); P inputs compared to crop uptake of P (b); K inputs compared to crop uptake of K (c). Outliers (>1.5 interquartile range) excluded.

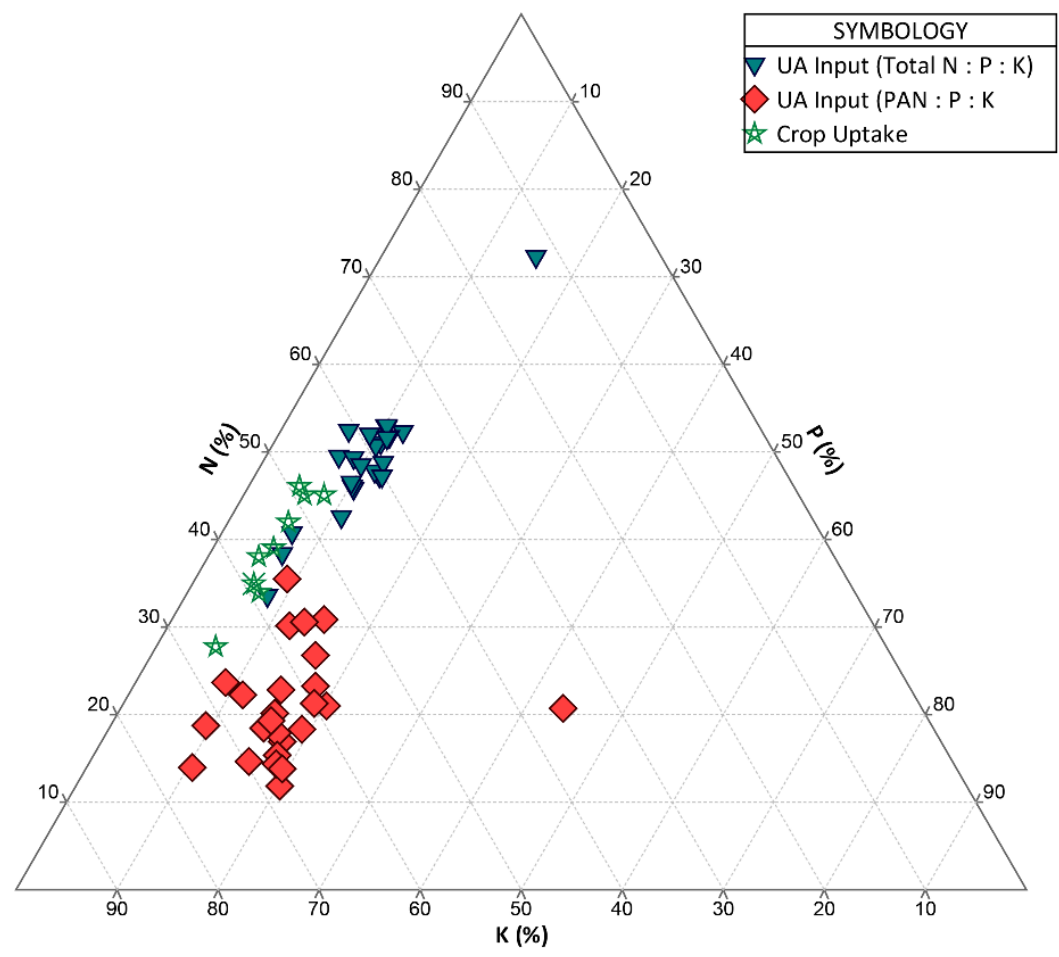

Figure 5. Comparison of ratios of nitrogen $(\mathrm{N})$, phosphorus $(\mathrm{P})$ and potassium $(\mathrm{K})$ inputs (shown separately for total $\mathrm{N}$ and plantavailable nitrogen (PAN)) for $25 \mathrm{UA}$ farms with ratios of N, P and K uptake for 10 common crops grown on urban farms (beet root, broccoli, red cabbage, carrot, celery, green bean, lettuce, onion, radish and spinach). The ratios are normalized to percentages (e.g. $\left.\mathrm{N}^{*}(\mathrm{~N}+\mathrm{P}+\mathrm{K})^{-1}\right)$. The $\mathrm{N}$ axis reads horizontally, the $\mathrm{P}$ axis reads diagonally from top right to bottom left and the $\mathrm{K}$ axis reads diagonally from bottom right to top left. 


\section{References}

Abdulkadir, A., Leffelaar, P. A., Agbenin, J. O. \& Giller, K. E. 2013. Nutrient flows and balances in urban and peri-urban agroecosystems of Kano, Nigeria. Nutrient cycling in agroecosystems, 95, 231-254.

Ackerman, K., Conard, M., Culligan, P., Plunz, R., Sutto, M.-P. \& Whittinghill, L. 2014. Sustainable food systems for future cities: The potential of urban agriculture. The economic and social review, 45, 189-206.

Artmann, M. \& Sartison, K. 2018. The Role of Urban Agriculture as a Nature-Based Solution: A Review for Developing a Systemic Assessment Framework. Sustainability, 10, 1-32.

Bergström, L., Kirchmann, H., Aronsson, H., Torstensson, G. \& Mattsson, L. 2009. Use efficiency and leaching of nutrients in organic and conventional cropping systems in Sweden. Organic Crop ProductionAmbitions and Limitations. Springer.

Berry, P., Sylvester-Bradley, R., Philipps, L., Hatch, D., Cuttle, S., Rayns, F. \& Gosling, P. 2002. Is the productivity of organic farms restricted by the supply of available nitrogen? Soil Use and Management, $18,248-255$.

Bosch, H. \& De Jonge, P. 1989. Handboek voor de Akkerbouw en de Groenteteelt in de Vollegrond 1989. PAGV.

Chrispim, M. C., Tarpeh, W. A., Salinas, D. T. \& Nolasco, M. A. 2017. The sanitation and urban agriculture nexus: urine collection and application as fertilizer in São Paulo, Brazil. Journal of Water Sanitation and Hygiene for Development, 7, 455-465.

Cohen, D. \& Crabtree, B. 2006. Qualitative Research Guidelines Project. $x$

de Haan, J. J. \& van Geel, W. 2013. Advies voor de bemesting van akkerbouw- en vollegrondsgroentengewassen. Praktijkonderzoek Plant \& Omgeving (PPO).

Deelstra, T. \& Girardet, H. 2000. Urban agriculture and sustainable cities. Bakker N., Dubbeling M., Gündel S., Sabel-Koshella U., de Zeeuw H. Growing cities, growing food. Urban agriculture on the policy agenda. Feldafing, Germany: Zentralstelle für Ernährung und Landwirtschaft (ZEL), 43-66.

Dewaelheyns, V., Elsen, A., Vandendriessche, H. \& Gulinck, H. 2013. Garden management and soil fertility in Flemish domestic gardens. Landscape and Urban Planning, 116, 25-35.

Drechsel, P. \& Kunze, D. 2001. Waste composting for urban and peri-urban agriculture: Closing the rural-urban nutrient cycle in sub-Saharan Africa, CABI.

Duchemin, E., Wegmuller, F. \& Legault, A.-M. 2008. Urban agriculture: multi-dimensional tools for social development in poor neighbourhoods. Field Actions Science Reports. The journal of field actions, 1.

Edwards, A. \& Withers, P. 1998. Soil phosphorus management and water quality: a UK perspective. Soil use and Management, 14, 124-130.

Eghball, B. 2002. Soil Properties as Influenced by Phosphorus- and Nitrogen-Based Manure and Compost Applications Joint contribution of USDA-ARS and Univ. of Nebraska Agric. Res. Div., Lincoln, NE, as paper no. 12996. Agronomy Journal, 94, 128-135.

Fink, M., Feller, C., Scharpf, H. C., Weier, U., Maync, A., Ziegler, J., Paschold, P. J. \& Strohmeyer, K. 1999. Nitrogen, phosphorus, potassium and magnesium contents of field vegetables-Recent data for fertiliser recommendations and nutrient balances. Journal of Plant Nutrition and Soil Science, 162, 7173.

Goldstein, B., Hauschild, M., Fernández, J. \& Birkved, M. 2016. Urban versus conventional agriculture taxonomy of resource profiles: a review. Agronomy for Sustainable Development, 36, 1-19.

Grard, B. J.-P., Bel, N., Marchal, N., Madre, F., Castell, J.-F., Cambier, P., Houot, S., Manouchehri, N. Besancon, S. \& Michel, J.-C. 2015. Recycling urban waste as possible use for rooftop vegetable garden. Future of Food: Journal on Food, Agriculture and Society, 3, 21-34.

Hargreaves, J. C., Adl, M. S. \& Warman, P. R. 2008. A review of the use of composted municipal solid waste in agriculture. Agriculture, Ecosystems \& Environment, 123, 1-14.

Hijbeek, R., van Ittersum, M. K., ten Berge, H. F. M., Gort, G., Spiegel, H. \& Whitmore, A. P. 2017. Do organic inputs matter - a meta-analysis of additional yield effects for arable crops in Europe. Plant and Soil, 411, 293-303.

Huang, B., Shi, X., Yu, D., Öborn, I., Blombäck, K., Pagella, T. F., Wang, H., Sun, W. \& Sinclair, F. L. 2006. Environmental assessment of small-scale vegetable farming systems in peri-urban areas of the Yangtze River Delta Region, China. Agriculture, Ecosystems \& Environment, 112, 391-402.

Kadaster, C.-B. 2012. CBS Bestand Bodemgebruik 2012.

Khai, N. M., Ha, P. Q. \& Öborn, I. 2007. Nutrient flows in small-scale peri-urban vegetable farming systems in Southeast Asia-a case study in Hanoi. Agriculture, Ecosystems \& Environment, 122, 192-202.

LeGrand, M., Clark, O. G. \& Chaoui, I. H. I. Rationalizing nutrient flows on an urban planet. American Society of Agricultural and Biological Engineers Annual International Meeting 2014, ASABE 2014, 2014. I: American Society of Agricultural and Biological Engineers, 2536-2542.

Lord, E., Johnson, P. \& Archer, J. 1999. Nitrate Sensitive Areas: a study of large scale control of nitrate loss in England. Soil Use and Management, 15, 201-207.

Lorenz, K. 2015. Organic urban agriculture. Soil Science, 180, 146-153.

Loveland, P. \& Webb, J. 2003. Is there a critical level of organic matter in the agricultural soils of temperate regions: a review. Soil and Tillage Research, 70, 1-18.

Maltais-Landry, G., Scow, K., Brennan, E., Torbert, E. \& Vitousek, P. 2016. Higher flexibility in input N: P ratios results in more balanced phosphorus budgets in two long-term experimental agroecosystems. Agriculture, Ecosystems \& Environment, 223, 197-210.

Maltais-Landry, G., Scow, K., Brennan, E. \& Vitousek, P. 2015. Long-Term Effects of Compost and Cover Crops on Soil Phosphorus in Two California Agroecosystems. Soil Science Society of America Journal, 79, 688-697.

McDonnell, M. J. \& MacGregor-Fors, I. 2016. The ecological future of cities. Science, 352, 936-938.

Meststoffenwet 1986. Uitvoeringsregeling Meststoffenwet. In: MINISTRY OF AGRICULTURE, N. A. F. Q. (ed.). 
Metson, G. S. \& Bennett, E. M. 2015. Phosphorus cycling in Montreal's food and urban agriculture systems. PLOS ONE, 10.

Mikkelsen, R. \& Hartz, T. K. 2008. Nitrogen Sources for Organic Crop Production. Better Crops, 92.

Mok, H.-F., Williamson, V. G., Grove, J. R., Burry, K., Barker, S. F. \& Hamilton, A. J. 2014. Strawberry fields forever? Urban agriculture in developed countries: a review. Agronomy for sustainable development, 34, 21-43.

Mulier, A., Hofman, G., Baecke, E., Carlier, L., De Brabander, D., De Groote, G., De Wilde, R., Fiems, L., Janssens, G. \& Van Cleemput, O. 2003. A methodology for the calculation of farm level nitrogen and phosphorus balances in Flemish agriculture. European Journal of Agronomy, 20, 45-51.

Öborn, I., Edwards, A., Witter, E., Oenema, O., Ivarsson, K., Withers, P., Nilsson, S. \& Stinzing, A. R. 2003. Element balances as a tool for sustainable nutrient management: a critical appraisal of their merits and limitations within an agronomic and environmental context. European Journal of Agronomy, 20, 211-225.

Pearson, L. J., Pearson, L. \& Pearson, C. J. 2010. Sustainable urban agriculture: stocktake and opportunities. International journal of agricultural sustainability, 8, 7-19.

Rees, W. \& Wackernagel, M. 1996. Urban ecological footprints: why cities cannot be sustainable-and why they are a key to sustainability. Environmental impact assessment review, 16, 223-248.

Revi, A. \& Rosenzweig, C. 2013. The urban opportunity: Enabling transformative and sustainable development. Background Research Paper for the High-Level Panel of Eminent Persons on the Post-2015 Development Agenda. New York, NY, USA: UN Sustainable Development Solutions Network.

RVO. Dierlijke mest gebruiksnorm en gebruiksruimte [Online]. Rijksdienst voor Ondernemend Nederland. Available: https://www.rvo.nl/onderwerpen/agrarischondernemen/mestbeleid/mest/gebruiksnormen/dierlijke-mest [Accessed 08/06/2018 2018].

RVO 2014. Tabel 3 Werkingscoëfficiënt 2014-2017. In: 2014-2017, M. (ed.) 01/01/2014 ed.: Rijksdienst voor Ondernemend Nederland.

RVO 2017a. Maximale waarden voor zware metalen. 01Mestbeleid 2017. 01/01/2017 ed.: Rijksdienst voor Ondernemend Nederland.

RVO 2017b. Tabel 1 Stikstofgebruiksnormen 2017. In: 2017, M. (ed.) 01/01/2017 ed.: Rijksdienst voor Ondernemend Nederland.

RVO 2017c. Tabel 4. Maximale waarden voor organische microverontreinigingen in meststoffen per kilogram van het desbetreffende waardegevende bestanddeel. 01Mestbeleid 2017. 01/01/2017 ed.: Rijksdienst voor Ondernemend Nederland.

Safi, Z. 2011. Nutrient cycling and nutrient use efficiency in urban and peri-urban agriculture of Kabul, Afghanistan. Doctor Doctoral dissertation, University of Kassel.

Schröder, J. J. \& Neeteson, J. J. 2008. Nutrient management regulations in The Netherlands. Geoderma, 144, 418-425.

Smit, J. \& Nasr, J. 1992. Urban agriculture for sustainable cities: using wastes and idle land and water bodies as resources. Environment and urbanization, 4, 141-152.

Smit, J., Nasr, J. \& Ratta, A. 1996. Urban agriculture: food, jobs and sustainable cities. New York, USA, 2, 3537.

Specht, K., Siebert, R., Hartmann, I., Freisinger, U. B., Sawicka, M., Werner, A., Thomaier, S., Henckel, D., Walk, H. \& Dierich, A. 2013. Urban agriculture of the future: an overview of sustainability aspects of food production in and on buildings. Agriculture and Human Values, 1-19.

Specht, K., Siebert, R. \& Thomaier, S. 2015. Perception and acceptance of agricultural production in and on urban buildings (ZFarming): a qualitative study from Berlin, Germany. Agriculture and Human Values.

Taylor, J. R. \& Lovell, S. T. 2014. Urban home food gardens in the Global North: research traditions and future directions. Agriculture and Human Values, 31, 285-305.

Thomaier, S., Specht, K., Henckel, D., Dierich, A., Siebert, R., Freisinger, U. B. \& Sawicka, M. 2015. Farming in and on urban buildings: Present practice and specific novelties of zero-acreage farming (ZFarming). Renewable Agriculture and Food Systems, 30, 43-54.

Tian, D. \& Niu, S. 2015. A global analysis of soil acidification caused by nitrogen addition. Environmental Research Letters, 10, 024019.

van Grinsven, H. \& Bleeker, A. 2016. Evaluation of the Manure and fertilisers Act 2016: Synthesis Report. Netherlands Environmental Assessment Agency (PBL).

Van Grinsven, H. J. M., Tiktak, A. \& Rougoor, C. W. 2016. Evaluation of the Dutch implementation of the nitrates directive, the water framework directive and the national emission ceilings directive. NJAS Wageningen Journal of Life Sciences, 78, 69-84.

Voytenko, Y., McCormick, K., Evans, J. \& Schliwa, G. 2016. Urban living labs for sustainability and low carbon cities in Europe: Towards a research agenda. Journal of Cleaner Production, 123, 45-54.

Wang, H.-J., Huang, B., Shi, X.-Z., Darilek, J. L., Yu, D.-S., Sun, W.-X., Zhao, Y.-C., Chang, Q. \& Öborn, I. 2008. Major nutrient balances in small-scale vegetable farming systems in peri-urban areas in China. Nutrient Cycling in Agroecosystems, 81, 203-218.

Wielemaker, R. C., Weijma, J. \& Zeeman, G. 2018. Harvest to harvest: Recovering nutrients with New Sanitation systems for reuse in Urban Agriculture. Resources, Conservation and Recycling.

Witzling, L., Wander, M. \& Phillips, E. 2011. Testing and educating on urban soil lead: A case of Chicago community gardens. Journal of Agriculture, Food Systems, and Community Development, 1, 167-185.

Wolfram, M. \& Frantzeskaki, N. 2016. Cities and systemic change for sustainability: prevailing epistemologies and an emerging research agenda. Sustainability, 8, 144.

Zasada, I. 2011. Multifunctional peri-urban agriculture-A review of societal demands and the provision of goods and services by farming. Land use policy, 28, 639-648. 